\title{
International medical migration: what is the future for Australia?
}

\author{
Despite goals for self-sufficiency, \\ migration seems certain to remain an \\ imperative for Australia for the \\ foreseeable future
}

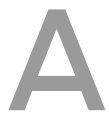
ustralia has developed extraordinary reliance on international medical graduates (IMGs) compared with other OECD (Organization for Economic Co-operation and Development) countries. Based on analysis of an unprecedented range of secondary data, I aim to define the recent scale and sources of medical migration, IMGs' immigration categories, their distribution, their performance in the Australian Medical Council examinations, and the impact of the Competent Authority Pathway.

From the 2005-06 financial year to 2010-11, 17910 IMGs were sponsored to Australia on a temporary basis, with a further 2790 selected as permanent skilled migrants. ${ }^{1,2}$ Thousands of additional IMGs arrived unfiltered in advance for human capital attributes, admitted as spouses and through Australia's family or humanitarian categories. Recent IMGs have trained in highly diverse countries, associated with very variable English language testing results and medical registration and employment outcomes.

Despite such challenges, I argue that Australia's reliance on IMGs is likely to be maintained in the future, owing to a combination of factors. First, medical migration remains Australia's key strategy for addressing medical workforce maldistribution, with competition to recruit and retain medical migrants recently intensifying rather than diminishing. Second, the Competent Authority Pathway for registration has improved IMGs' outcomes, enhancing their immediate value as a source of supply. Third, Australia has become increasingly reliant on internationally trained specialists to serve in select undersupplied fields. Fourth, there is growing Australian demand for international medical students, who achieve exceptional early outcomes relative to IMGs. Despite greatly enhanced investment in domestic student training, Australia's dependence on international migration thus appears likely to persist rather than reduce in the foreseeable future.

\section{Australia's level of dependence on medical migrants}

By $2006,45 \%$ of medically qualified residents were overseas-born, including an estimated $25 \%$ who were overseas-qualified. ${ }^{3}$ In 2001-2006, 7596 doctors migrated to Australia across all immigration categories - double the number admitted from 1996 to 2000 . India, the United Kingdom/Ireland, Sri Lanka/Bangladesh, China, other southern and central Asian countries, North Africa/ the Middle East, South Africa, sub-Saharan Africa (excluding South Africa), and the Philippines were the primary source countries at this time (Box 1$){ }^{4}$

Medical workforce diversification has proven challenging, however. Just $53 \%$ of IMGs who arrived in Australia during 2001-2006 secured medical employment by 2006 (across all immigration categories). Doctors from English-speaking countries made the transition seamlessly, while Asian-Commonwealth doctors from countries such as Singapore and Malaysia, India, Sri Lanka and Bangladesh fared reasonably well. Outcomes were poor for many other birthplace groups (Box 1). Just $6 \%$ from China had found medical employment within 5 years, 23\% from Vietnam and 31\% from Eastern Europe. Many had arrived through the family and humanitarian categories - untested in advance for employment attributes or registerability. ${ }^{4}$ Thousands were also admitted as spouses. Large numbers of recently arrived IMGs were defined as "not in the labour force" - a proxy for learning English and/or trying to pass preregistration exams. English testing for example was a powerful barrier. By 2010, a pass rate of only $43 \%$ was the Occupational English Test norm for medical applicants, rising to $52 \%$ in $2011 .{ }^{1}$

Despite highly diverse source countries, workforce integration is best for IMGs selected through Australia's 457 visa temporary sponsored pathway (99\% employed at 6 months), followed by those entering under the permanent General Skilled Migration Program. These flows now dominate (Box 2). This pathway is highly attractive to governments and employers given the potential to prescribe IMGs' location as a condition of visa entry, allowing them to work for up to 4 years at undersupplied sites.

By $2009,70 \%$ of labour migrants were sponsored, reflecting the recent dramatic privatisation of Australia's skilled migration program. From 2005-06 to 2009-10, 34870 health professionals were selected as temporary 457 visa migrants. Nurses (46\%) and doctors (44\%) dominated. A further 2420 visas were awarded to temporary IMGs in 2010-11: 1190 for general medical practitioners and 1230 for resident (house) medical officers (mostly new appointments). In 2010-11, most such IMGs were recruited to Victoria (600), New South Wales (540), Queensland (500) and Western Australia (280). ${ }^{2}$ From 2004-05 to 2009-10 an additional 15940 General Skilled Migration category migrants holding health qualifications were admitted permanently, primarily qualified in nursing (52\%), medicine (15\%) and pharmacy (13\%). In 2010-11, 460 more IMGs were approved. $^{1,2}$

Additional doctors arrive from New Zealand enjoying free entry rights under the Trans-Tasman 
Mutual Recognition Arrangement, in a context where $12 \%$ of the New Zealand population is currently resident in Australia. By 2006, 1163 New Zealand physicians were based in Australia, including 240 admitted from 2001 to 2006. ${ }^{1}$

\section{Performance in the Australian Medical Council examinations}

New Zealand doctors face no employment barriers in Australia. Analysis of 28 years of Australian Medical Council (AMC) data, however, reveals that other IMGs experience highly variable registration outcomes. The most detailed study to date, commissioned by the Department of Health and Ageing, showed that just a third of recently arrived IMGs had attempted to pass the AMC preaccreditation exams in the years preceding 2007. Of those IMGs attempting it, 78\% were medically employed within 5 years, despite just $41 \%$ having by then secured unconditional registration. ${ }^{5}$

According to the AMC Submission to the House of Representatives Standing Committee on Health and Ageing Inquiry into Registration Processes and Support for Overseas Trained Doctors (2011) and additional data provided to me, from 2004-10, 57\% of IMGs aged 21-30 years passed the multiple choice question examination on their first attempt, compared with $46 \%$ aged $41-50$ years and $31 \%$ aged over 50 . Similar trends were evident in the clinical examination. ${ }^{6}$ Box 3 reports outcomes by the top 10 countries of training.

In 2008, given mounting concern, the Australian Government initiated "a national assessment process for overseas qualified doctors to ensure appropriate standards in qualifications and training as well as increase the efficiency of the assessment process" ${ }^{7}$ Multiple pathways to practice have since developed, including the fast-track "Competent Authority" option for doctors registered in New Zealand, the UK, Ireland, the United States and Canada. Eligible source countries may opt out Singapore and South Africa have done so to minimise workforce loss. ${ }^{6}$ For IMGs requiring greater periods of adjustment, alternative pathways have been designed to provide enhanced supervision, address differential levels of training need, and increase readiness for specific locations of practice.

\section{Factors affecting Australia's reliance on IMGs}

To redress medical workforce undersupply, Health Workforce Australia has been charged by the Australian Health Ministers' Conference with developing a national training plan. The goal is to reach self-sufficiency by 2025 .

In the foreseeable future, however, medical migration seems certain to remain an imperative for Australia, given Australia's ageing patient and practitioner base, reduced hours worked by younger cohorts, the growing feminisation of medicine, limited access to internship places, and distribution challenges. The Department of Immigration and Citizenship has recently set "occupation ceilings" for skilled migration in 2012-13. In medicine, the ceiling is 4860 people, compared with 15660 in nursing,

\begin{tabular}{|c|c|c|c|c|c|c|}
\hline \multirow[b]{2}{*}{ Birth country } & \multirow[b]{2}{*}{ Number } & \multicolumn{3}{|c|}{ Employed } & \multicolumn{2}{|c|}{ Other } \\
\hline & & $\begin{array}{c}\text { Own } \\
\text { profession }\end{array}$ & $\begin{array}{l}\text { Other } \\
\text { profession }\end{array}$ & $\begin{array}{l}\text { Sub- } \\
\text { total }\end{array}$ & $\begin{array}{l}\text { Un- } \\
\text { employed }\end{array}$ & NLF \\
\hline Australia/New Zealand & 39381 & $58 \%$ & $29 \%$ & $88 \%$ & $1 \%$ & $12 \%$ \\
\hline United Kingdom/Ireland & 1004 & $71 \%$ & $14 \%$ & $85 \%$ & - & $15 \%$ \\
\hline Northern Europe & 39 & $51 \%$ & $18 \%$ & $69 \%$ & - & $31 \%$ \\
\hline Western Europe & 328 & $62 \%$ & $20 \%$ & $81 \%$ & $2 \%$ & $17 \%$ \\
\hline South-eastern Europe & 132 & $49 \%$ & $24 \%$ & $73 \%$ & $2 \%$ & $25 \%$ \\
\hline Eastern Europe & 160 & $31 \%$ & $26 \%$ & $56 \%$ & $6 \%$ & $38 \%$ \\
\hline Vietnam & 64 & $23 \%$ & $25 \%$ & $48 \%$ & $5 \%$ & $47 \%$ \\
\hline Indonesia & 73 & $8 \%$ & $16 \%$ & $25 \%$ & $16 \%$ & $59 \%$ \\
\hline Malaysia & 227 & $62 \%$ & $5 \%$ & $67 \%$ & $3 \%$ & $30 \%$ \\
\hline Philippines & 256 & $50 \%$ & $27 \%$ & $77 \%$ & $5 \%$ & $19 \%$ \\
\hline Singapore & 65 & $63 \%$ & $14 \%$ & $77 \%$ & - & $23 \%$ \\
\hline China (not SAR or Taiwan) & 590 & $6 \%$ & $47 \%$ & $53 \%$ & $11 \%$ & $36 \%$ \\
\hline Hong Kong/Macau & 38 & $40 \%$ & $40 \%$ & $79 \%$ & - & $21 \%$ \\
\hline Japan/South Korea & 102 & $14 \%$ & $28 \%$ & $42 \%$ & $10 \%$ & $48 \%$ \\
\hline Other southern and central Asia & 364 & $43 \%$ & $10 \%$ & $53 \%$ & $7 \%$ & $40 \%$ \\
\hline India & 1378 & $61 \%$ & $12 \%$ & $73 \%$ & $7 \%$ & $20 \%$ \\
\hline Sri Lanka/Bangladesh & 691 & $56 \%$ & $16 \%$ & $71 \%$ & $7 \%$ & $21 \%$ \\
\hline Canada/United States & 201 & $48 \%$ & $17 \%$ & $65 \%$ & $2 \%$ & $33 \%$ \\
\hline Central/South America & 117 & $40 \%$ & $30 \%$ & $70 \%$ & $13 \%$ & $17 \%$ \\
\hline South Africa & 496 & $75 \%$ & $18 \%$ & $93 \%$ & $1 \%$ & $5 \%$ \\
\hline Other sub-Saharan Africa & 342 & $71 \%$ & $6 \%$ & $77 \%$ & $7 \%$ & $16 \%$ \\
\hline North Africa/Middle East & 564 & $47 \%$ & $13 \%$ & $60 \%$ & $10 \%$ & $31 \%$ \\
\hline Other & 365 & $56 \%$ & $20 \%$ & $75 \%$ & $3 \%$ & $22 \%$ \\
\hline Total migrants & 7596 & $53 \%$ & $18 \%$ & $71 \%$ & $6 \%$ & $23 \%$ \\
\hline
\end{tabular}

$\mathrm{NLF}=$ not in the labour force. SAR = Special Administrative Region. - = insufficient cases for reliable reporting and issues of confidentiality. Many of the cells are based on very small numbers, therefore the results should be regarded as indicative only.

* Source: UNESCO global comparison study, Table 23. ${ }^{4}$ Excludes those for whom birthplace or year of arrival is unknown. Due to missing data, imputation and aggregation, numbers may not add up to $100 \%$.

1380 in pharmacy and 720 in dentistry (numbers are reported at http://www.immi.gov.au/skills/skillselect).

\section{Migration remains Australia's key strategy for redressing medical workforce maldistribution, with states intensifying competition to recruit and retain IMGs}

Between June 2000 and December 2002, 5304 temporary IMGs were sponsored to "areas of need". This level of dependence has been maintained, with 3860 IMGs selected by states or territories in 2007-08 compared with 3310 a year later. In 2008-09, based on state and territory medical board or medical council data, 17141 doctors were employed under various forms of conditional registration. Further, 2695 IMGs were employed through "area of need" registrations (primarily in Queensland [50\%]), with Australia remaining highly reliant on medical migrants for primary care in remote or very remote sites. ${ }^{3}$ Definitions of eligible areas have also been extended rather than reduced. In 2007, larger regional centres characterised by significant workforce shortages were included. ${ }^{8}$ Following 5 years of service in an area of need, IMGs can apply for permanent resident status. $^{2}$ 


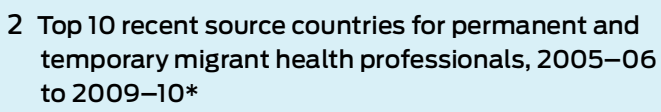

2 Top 10 recent source countries for permanent and temporary migrant health professionals, 2005-06 to 2009-10*

\begin{tabular}{lccc} 
Country & $\begin{array}{c}\text { Permanent } \\
\text { migrant health } \\
\text { professionals }\end{array}$ & Country & $\begin{array}{c}\text { Temporary } \\
\text { migrant health } \\
\text { professionals }\end{array}$ \\
\hline United Kingdom & 4120 & United Kingdom & 9350 \\
India & 1510 & India & 6420 \\
Malaysia & 1300 & Philippines & 1850 \\
China & 970 & South Africa & 1770 \\
\hline Philippines & 510 & Malaysia & 1570 \\
South Africa & 500 & Ireland & 1560 \\
Republic of Korea & 480 & China & 1380 \\
Egypt & 420 & Zimbabwe & 1180 \\
Singapore & 390 & Canada & 950 \\
Ireland & 350 & United States & 830 \\
\hline
\end{tabular}

* Source: Scoping paper for Health Workforce Australia, Table 6, p. 51 , based on Department of Immigration and Citizenship data, reported by financial year. ${ }^{1} \dagger$ General skilled migration primary applicants; total all sources, 13880 . $¥ 457$ long-stay business visa primary applicants; total all sources, 34870 .

By $2010,46 \%$ of doctors in rural and remote practice in Queensland were overseas-trained. Thirty-six per cent of the 1209 GPs working in rural and remote Victoria had obtained their basic medical qualification outside Australia, primarily in south Asia (11\%), the UK or Ireland (7\%), Africa (5\%), eastern Europe (4\%) and the Middle East (3\%). IMGs constituted $53 \%$ of rural and remote GPs in WA, and were derived from 33 countries of training double the level of reliance in 2002. ${ }^{9-12}$ The majority were 457 visa (or equivalent) temporary sponsored arrivals, typically working under various forms of conditional registration. This practice has become widespread in the past decade, despite growing concerns for the risk of developing "two-tier" medical care. ${ }^{6}$ New governance systems have been introduced through the 2010 establishment of the Australian Health Practitioner Regulation Agency; ${ }^{13,14}$ however, these have coincided with concern about red tape related to changed recruitment and registration procedures. ${ }^{15}$

\section{Australia's Competent Authority pathway has recently transformed IMG recruitment while enhancing their value as a source of supply}

From July 2007 to late 2010, 4955 Competent Authority applications were received by the AMC, and 3327 Certificates of Advanced Standing were issued. This process had been successfully completed by 1990 applicants from 56 countries of training by December 2010, a year when 1281 assessments were handled. ${ }^{6}$ In an unanticipated consequence, the Competent Authority model also enhanced Australia's global competitiveness. From 2007-10, the Competent Authority pathway attracted relatively young applicants; $54 \%$ of those issued Advanced Standing Certificates were aged 21-30 years, compared with $38 \%$ aged $31-40$ years. UK-trained applicants were the major beneficiaries (1019), followed by IMGs qualified in India (422) and Ireland (176). Massive growth in arrivals who qualified in the UK or Ireland has occurred, surging to around 3000 in 2007-10, compared with up to a hundred per year previously. ${ }^{16}$ These IMGs enjoy strong employment outcomes, despite debate over a registration scheme that allows thousands of IMGs to practise on a supervised basis.

\section{Australia has become increasingly reliant on internationally trained medical specialists to serve in undersupplied fields}

In recent decades, Australia's dependence on IMGs has also become marked in select specialties. From 2004 to 2010 the AMC handled 6604 IMG specialist applications, primarily in the fields of anaesthesia $(13 \%)$, psychiatry (11\%), obstetrics and gynaecology (8\%), diagnostic radiology $(8 \%)$ and general surgery $(6 \%) .{ }^{1}$ Most were from men $(69 \%)$, with the top five countries of training being the UK, India, South Africa, the USA and Germany.

In terms of psychiatry, for example, disproportionate numbers of IMGs now work on temporary 457 visas in underserved sites. ${ }^{17,18}$ They compensate for an exodus of domestic psychiatrists from public sector and regional practice, who work in large cities in affluent suburbs, near private hospitals where they admit their patients. ${ }^{19}$ Rural psychiatrists, by contrast, typically lack access to urban amenities, quality schools and employment for their spouse. Many are on call 24 hours per day, 7 days a week, providing mental health services in regions characterised by gross undersupply. ${ }^{19}$ Comparable IMG dependence prevails in many specialties.

\section{There is now growing Australian demand to recruit and retain international medical students}

Former international students have emerged as a key medical resource for Australia. By definition they are characterised by youth, full registration, and significant acculturation. They have funded themselves to meet Australian professional standards, and face none of the IMGs' barriers.

By December 2009, close to 3000 international students were enrolled in medical courses (and this has since accelerated). In 1999, following removal of a 3-year eligibility bar, they became immediately able to migrate. ${ }^{20}$ As demonstrated by Australia's Graduate Destination Survey, since 2006, retention of international medical students has tripled, with large numbers wishing to

3 Australian Medical Council clinical examination outcomes by top 10 countries of training, 2004-2010*

\begin{tabular}{lcccc}
$\begin{array}{l}\text { Top } 10 \text { countries } \\
\text { of training }\end{array}$ & $\begin{array}{c}\text { No. of } \\
\text { candidates }\end{array}$ & Pass & Fail & Retest \\
\hline India & 1823 & $52 \%$ & $29 \%$ & $19 \%$ \\
\hline Bangladesh & 799 & $42 \%$ & $38 \%$ & $20 \%$ \\
\hline Pakistan & 665 & $48 \%$ & $31 \%$ & $21 \%$ \\
\hline Sri Lanka & 660 & $58 \%$ & $22 \%$ & $20 \%$ \\
\hline China & 594 & $58 \%$ & $23 \%$ & $19 \%$ \\
\hline Iran & 481 & $56 \%$ & $27 \%$ & $17 \%$ \\
\hline Philippines & 437 & $34 \%$ & $46 \%$ & $20 \%$ \\
\hline Burma & 374 & $47 \%$ & $31 \%$ & $22 \%$ \\
\hline Iraq & 333 & $52 \%$ & $29 \%$ & $19 \%$ \\
\hline Egypt & 277 & $52 \%$ & $29 \%$ & $19 \%$ \\
\hline Other countries & 2646 & $58 \%$ & $26 \%$ & $16 \%$ \\
\hline Total candidates & 9089 & $53 \%$ & $29 \%$ & $19 \%$ \\
\hline * Source: Scoping paper for Health Workforce Australia, Table 29, p. 97, 1 \\
based on Australian Medical Council data, reported by calendar year.
\end{tabular}


migrate. They achieve nearly identical immediate employment and salary outcomes to domestic graduates. By 2010, 98.9\% were employed full-time, compared with $99.7 \%$ of domestic graduates. Analysis of the Medical Schools Outcomes Database and Longitudinal Tracking Project shows $78 \%$ of final-year international students initially stay - virtually all graduates, once sponsored students are excluded. ${ }^{21,22}$ While the ethics of international student migration remain a matter of debate, parents rather than source countries have resourced their education. From an ethical perspective, their recruitment is less problematic than the normal recruitment method of OECD countries - selection of mature-age medical professionals fully trained by their countries of origin. ${ }^{23,24}$

\section{Conclusion}

Between 2004 and 2009, the number of Australian domestic medical completions rose from 1287 to 1915. Provisional registrations rose from 1699 to $2955 .^{25}$ Incentive schemes were also developed (most notably the Bonded Medical Places Scheme, to which 25\% of all firstyear Commonwealth supported medical school places are allocated) to encourage medical graduates to serve in areas with an undersupply of doctors. Despite such measures, dependence on IMGs seems certain to remain strong, as confirmed by the recent House of Representatives inquiry into overseas-trained doctors. ${ }^{15}$ Australia is not alone in this reliance, which is intensifying across OECD nations. ${ }^{26-29}$ The challenge will be positioning to recruit and retain "the best" medical migrants, in the context of the highly variable registration and employment outcomes that many initially achieve. To facilitate this, collective action by all relevant jurisdictions will be essential.

Acknowledgement: I acknowledge with gratitude Health Workforce Australia's funding support, while noting that the views reported in this article are solely my own. This article draws on data reported in the scoping paper commissioned by HWA. The full report will be available shortly on the HWA website, following consideration by the federal, state and territory health ministers

Competing interests: No relevant disclosures.

Provenance: Commissioned; externally peer reviewed.

1 Hawthorne L. Health workforce migration to Australia - policy trends and outcomes 2004-2010. Scoping paper for Health Workforce Australia. Adelaide, 2011

2 Birrell B. Australia's new health crisis - too many doctors. Research report. Melbourne: Centre for Population and Urban Research, Monash University, 2011. http://arts.monash.edu.au/cpur/--downloads/ australias-new-health-crisis.pdf (accessed May 2012).

3 Australian Institute of Health and Welfare. Medical labour force 2009. Canberra: AlHW, 201l. http://www.aihw.gov.au/publication-detail/?id= 10737419680 (accessed Sep 2011).

4 Hawthorne L. UNESCO global comparison study. Migration and education: quality assurance and mutual recognition of qualifications - country report Australia. Paris: UNESCO, 2008. http:// unesdoc.unesco.org/images/0017/001798/179842E.pdf (accessed Dec 2008).

5 Hawthorne L, Hawthorne G, Crotty B. The registration and training status of overseas trained doctors in Australia. Melbourne: Faculty of Medicine, Dentistry and Health Sciences, University of Melbourne, 2007. http://www.health.gov.au/internet/main/publishing.nsf/Content/ D949ABAA95DCE77FCA2572AD007E1710/\$File/otdreg.pdf (accessed Jun 2012).

6 Australian Medical Council. Submission to the House of Representatives Standing Committee on Health and Ageing Inquiry into registration processes and support for overseas trained doctors. Submission No. 42; 4 Feb 201l. http://www.aph.gov.au/Parliamentary_ Business/Committees/House_of_Representatives_Committees?url= haa/overseasdoctors/subs.htm (accessed May 2012).

7 McLean R, Bennett J: Implementation and Technical Committees of the Australian Health Ministers' Advisory Council. Nationally consistent assessment of international medical graduates. Med J Aust 2008; 188: 464-468

8 Department of Health and Ageing. Rural other medical practitioners program. Guidelines. Canberra: DoHA, 2008. http://www.health.gov.au/ internet/main/publishing.nsf/Content/

ADCCA9CC97C9BE10CA2572F100797C2F/\$File/ROMPsProgram

Guidelines-Jan2011.pdf (accessed May 2012).

9 Rural Workforce Agency, Victoria. RWAV 2010 - Policy and Outreach Services. Melbourne: RWA. www.rwav.com.au (accessed Jun 2011).

10 Health Workforce Queensland. Medical practice in rural and remote Queensland: minimum data set (MDS) report as at 30th November 2011. Brisbane: HWQ, 20ll. http://www.healthworkforce.com.au/ Main.asp?NodelD=27677 (accessed May 2012)

11 Rural Health West. Minimum data set report and workforce analysis: 30 November 2010. Perth: Rural Health West, 2011. http:// www.ruralhealthwest.com.au/go/about-us/publications (accessed May 2012)

12 West Australian Country Health Service. Engaging rural doctors: final report 2007. Perth: WACHS, 2007.

13 National Health Workforce Taskforce. National accreditation and registration scheme. http://www.ahwo.gov.au/natreg.asp (accessed Dec 2010).

14 Australian Health Practitioner Regulation Agency. Registration. http:// www.ahpra.gov.au/Registration.aspx (accessed May 2012).

15 House of Representatives Standing Committee on Health and Ageing. Lost in the labyrinth. Report on the inquiry into registration processes and support for overseas trained doctors. Canberra: Commonwealth of Australia, 2012. http://www.aph.gov.au/Parliamentary_Business/ Committees/House of Representatives Committees?url=haa/ overseasdoctors/report.htm (accessed May 2012).

16 Frank I. Panel 3: mutual recognition of academic qualifications and professional credentials - physicians. Presented at the CanadaAustralia Roundtable on Foreign Qualification Recognition; 2011 April 12-15; Melbourne, Australia.

17 Australian Medical Workforce Advisory Committee. The specialist psychiatry workforce in Australia: supply, requirements and projections 1999-2010. AMWAC report 1999.7. North Sydney: AMWAC 1999.

18 Birrell B, Hawthorne L, Rapson V. The outlook for surgical services in Australasia. Melbourne: Royal Australasian College of Surgeons, 2003. http://www.surgeons.org/media/294115/Outlook_for_Surgical Services_in_Australasia_\%28Birrell_report\%29.pdf (accessed May 2012)

19 Barton D, Hawthorne L, Singh B, Little J. Victoria's dependence on overseas trained doctors in psychiatry. People and Place 2003; 11: 54-64

20 Hawthorne L. How valuable is "two-step migration"? Labour market outcomes for international student migrants to Australia. Asia and Pacific Migration Journal 2010; 19: 5-36.

21 Hawthorne L, To AW. The early migration and career trajectories of international medical students qualified in Australia. A Medical Schools Outcomes Database and Longitudinal Tracking Project. Sydney: 2012. Available on request from the Medical Deans of Australasia

22 Hawthorne L, Hamilton J. International medical students and migration: the missing dimension in Australian workforce planning? Med J Aust 2010: 193: 262-265.

23 Organisation for Economic Co-operation and Development. The looming crisis in the health workforce: how can OECD countries respond? OECD Health Policy Studies. Paris: OECD, 2008. http:// www.who.int/hrh/migration/looming_crisis_health_workforce.pdf (accessed May 2012).

24 Simoens S. Hurst J. The supply of physician services in OECD countries. OECD Health Working Papers No. 21. Paris: OECD, 2006. http://www.oecd.org/dataoecd/27/22/35987490.pdf (accessed May 2012)

25 Medical Deans, Australia and New Zealand. Medical school graduates 1996-2009. Sydney: 2010.

26 Medical Council of New Zealand. Medical Council of New Zealand annual report 2009. Wellington: MCNZ, 2009. http://www.mcnz.org.nz/ assets/News-and-Publications/Annual-Reports/MCNZ-AnnualReport-2009.pdf (accessed May 2012)

27 Hawthorne L; New Zealand Department of Labour. Competing for skills: migration policies and trends in New Zealand and Australia. Full report. Wellington: Department of Labour, 201l. http:// www.immi.gov.au/media/publications/research/_pdf/migrationpolicies-trends-fullreport.pdf (accessed May 2012).

28 Hawthorne L, Wong W. Australia-Canada Roundtable on Foreign Qualification Recognition - Backgrounder. Ottawa: Public Policy Forum, 2011. http://www.ppforum.ca/sites/default/files/ Backgrounder\%20\%28EN\%29.pdf (accessed May 2012).

29 Hawthorne L. Best practices in foreign quailfication recognition Australia. Australia-Canada Roundtable on Foreign Qualification Recognition - Annex 2. Ottawa: Public Policy Forum, 2011. http:// www.ppforum.ca/sites/default/files/Annex\%202.pdf (accessed May 2012). 